\title{
Promoting Foods to Indian Children through Product Packaging
}

\section{Soni Pavleen}

\begin{abstract}
Packaging serves as an important mass communication tool to market foods in stores. Packaging elements such as bright colours, spokes/cartoon characters, cartoonish scripts/crayoned fonts, discounts and premiums are used to attract children and influence their consumption behaviour. Use of these practices is widely researched in developed countries. However, these practices are witnessed to be used in developing countries like India as well. So, it is important to objectively assess the nature and extent of promotions used on food packages in Indian settings. The present study is based on content analysis of food packages. It is found that Indian children are exposed to a wide range of food promotions through food packaging. The extent of promotions used in India is very similar to the practices followed in other countries. Implications of these practices are finally discussed in the paper.
\end{abstract}

Keywords: food promotion, packaging, India, children

JEL Classification: $M 3$

\section{INTRODUCTION}

Marketers try to influence food preferences of children through product packaging. Packaging is an important tool as it communicates brand personality through colour, logo, shape, size and material of the package. Children are generally influenced by these features of the package. By examining the package they try to ascertain whether they would like the product or not. Therefore, associations with the package are also seen to be built through TV advertising. This helps to create awareness, facilitate identification and create differentiation for the brand in stores. Nonetheless, the logos, jingles, price discounts or other promotions that are highlighted in ads are reinforced through packages and are also better recalled by children (Ulger, 2009). As children also mainly focus on emotional appeals/themes to select foods (Page and Brewster, 2007), marketers specifically orient food packaging towards children by the application of promotions (Hawkes, 2010). Notably, these include competitions, collector promotions and premiums; using nutrition and health related information and/or claims; use of specific colours, sizes, shapes; typescripts for different written pieces of information; depicting brand or brand characters and using packaging 'technology' such as addition of straws, how it open and closes, how freshness is maintained, durability, etc.

The visual appeal is, thus, being witnessed to be vigorously crafted to suit the preferences of children. Chareonsakdi (2009) has found that use of colours, spokes-characters, bubble/cartoonish scripts, illustrations, appealing name/copy and augmentation are most commonly used by marketers. Foods are also promoted using taste appeals, associated fun, the product is propagated as 'new', the health benefits of consuming a product are highlighted and it is pointed out that 
the product contains 'essential nutrients' (Kaiser Family Foundation, 2007). Children not only respond to the box packaging, but also to the shapes and themes of the products. According to one study, themed cereal shapes are used to extend the effect of spokes-characters and branding efforts by adding a level of entertainment to eating (Macklin, 1996). The association between foods and entertainment is so strong that these foods are labelled as 'fun foods' (Elliot, 2008).

Younger children, being in the lower stage of cognitive development, are particularly seen to focus on premiums or other incentives to choose foods (Atkin, 1978; Roberts, 2005; Maher et al., 2006; Ulger and Ulger, 2012). It is also found that food promotions on packages are focussed on children (Chapman et al., 2006, Harris et al., 2010, Hebden et al., 2011). Ogba and Johnson (2010) report that these packaging characteristics strongly influence purchase behaviour of children in retail stores. Marketing strategies in lower income countries are also found to promote low nutritional foods and with the same intensity as it is done in the developed countries (Witkowski, 2007; Cairns et al., 2013). Therefore, it is imperative to answer the following research questions.

1. Are promotions are directed at Indian children with same intensity as they are done for children in developed countries?

2. Do multinational companies market foods in India with greater intensity than Indian companies?

As Indian children play a pivotal role in influencing food purchase decisions of parents in retail stores (Kaur and Singh, 2010), the present paper seeks to answer these questions. Based on the findings, it can then be inferred whether Indian children need suitable protection from food promotions and in a manner as their western counterparts are receiving.

\section{REVIEW OF PREVIOUS STUDIES}

Previous research has documented that package designs have a strong influence on children's product choice (Gelperowic and Beharrel, 1994; Wilson and Wood, 2004; Berry and McMullen, 2008; Ogba and Johnson, 2010). Children generally prefer longer wavelength colours that are in the right side of the colour spectrum, such as red, yellow, green and orange (Meyers and Lubliner, 1998; Carruth et al., 2000; Young, 2003). Licensed characters are important because they aid brand recognition and interaction for children, especially the young ones, who are less able to engage with a product through written words (Neeley and Schumann, 2004). Ulger (2009) further found that spokes-characters on packages have stronger influence on children's food choices as compared to TV advertising. Moreover, if the spokes-characters depicted in ads are wired through the packages, they tend to enhance communication with children.

Chapman et al. (2006) recorded the amount and type of food promotion within seven food categories - sweet biscuits, snack foods, confectionery, chips/savoury snacks, cereals, dairy snacks and ice-creams in supermarkets. They found that promotions were most commonly used for confectionery, dairy snacks and snack foods. It was also felt that a large proportion of promotions were used to market unhealthy foods. Cartoon characters and movie celebrities were most commonly used to promote these foods and multiple methods of promotion on individual prod- 
ucts were found. Further, the snack food category showed the greatest level of multiple food promotion usage. Page et al. (2008) examined cereal packages for promotional techniques. This included front panel characteristics, premium offers, cross promotions, activity features, characters and celebrities, websites and other content features. The results revealed that cereal packages used a variety of promotional techniques such as children favourite characters, movie and TV characters, an enlarged image of the cereal usually in a Ready-to-Eat fashion in a bowl, floating atop of milk. Most of them advertised about grains and other ingredients that might attract kids. Cereal boxes also offered activities to engage children and posted interesting facts or trivia and solving activities to engage children. In another study, Berry and McMullen (2008) collected information from cereal boxes drawn from Canadian supermarkets to examine marketing practices for ready to eat breakfast cereals targeted at children. It was found that approximately thirty two percent of cereal boxes used spokes-characters or focused on child centred incentives/premiums, nearly half of them used child friendly colours and some of them were oversized boxes (promoted as a family pack or a value size box). The ready to eat breakfast cereals marketed to children (using spokes characters, child themed shape or incentives) contained more sugar, trans-fats and used refined grains based formulas and were, thus, unhealthy. Consumers International (2008) findings of a survey in 32 countries (including India) on marketing tactics used by leading food marketing companies like Kellogg's and Nestle to promote RTE (Ready-To-Eat) cereals highlighted that these companies use a large number of promotional techniques such as cartoon characters, film tie-ins on packaging, giveaway toys, games, and competitions. Harris et al. (2010) analyzed cross promotions targeted to children and adolescents through packaging in the super markets. They found that over half of the promotions were targeted at children. A majority of promotions were found to concentrate on food categories such as cereals, fruit snacks, meat products, frozen desserts and candy. Promotions were executed through third party licensed characters from TV or movies. However, other types of TV and movie promotions, toys, games, sports teams and celebrities were also represented. Mehta et al. (2012) report that graphics, cartoon, celebrities and claims about nutrition are most commonly used to promote foods directed at children.

The foregoing review suggests that child incentives and premiums are seen to be widely used to attract children. However, only few studies have been conducted so far in this area and particularly no such study, to the extent of researcher's knowledge, has been conducted in India. So, the present study aims to bridge gaps in existing literature.

\section{RESEARCH METHODOLOGY}

The present study has been divided into two phases. In the first phase, primary information has been collected from respondents about food products and brands they buy for children. In the second phase, product packages of brands, identified in the first phase, have been content analysed for use of marketing tactics on food packages.

\section{Phase one of the study}

Responses were sought from mothers of children in age category 6-7 years who were approached through a school in the city of Amritsar (Punjab state of India). A questionnaire was given to the 
children studying in Grade 1 and they were asked to take it home and get it filled by the mother. Out of 200 questionnaires administered, 145 complete questionnaires were received with complete responses. This sample of 145 mothers comprised of housewives, primarily, who were well educated, belonged to middle income category and lived in extended families (husband, wife, children and grandparents). The responses of mothers revealed that children mainly preferred foods from six product categories_-beverages (including soft drinks, fruit juices and milk based drinks), confectionery (toffees, candies, chocolates, gems, and poppins), baked products (biscuits and cakes), snacks (potato chips, potato wafers, other Namkeen (Indian salted snacks)), Readyto-Cook (RTC) foods (noodles and pasta) and ice-creams. Baked products and RTC foods were however most frequently requested from parents and also consumed.

\section{Phase two of the study}

In the second phase of the study, product packages of brands (identified in the first phase) were studied for marketing tactics deployed. 107 packages of food items were used in the study. Brands were selected using proportionate sampling from the reported frequencies of purchasing these foods by mothers in phase one of the study (refer Table 1). Operational definitions for identifying food promotions used on packages were followed using the typology of Mehta et al. (2010). These included - package semiotics (graphics, text, colour, claims about nutrition, iconography, popular personalities), cross promotions (tie-ins with television/films, directed to websites), novelty packaging, premium promotions (competitions, toys, games) and price promotions (discounts, bonus sized packs).

Semiotics was further sub-categorized as follows:

1. Child-oriented graphics: bright colours; images of children or animals; childish script; references to play, education, flavours, colour or shapes; captions exaggerating attributes, e.g. Britannia Tiger biscuits "iron zor (strength) helps make your mind sharper and body, stronger, zero trans-fat".

2. Child-oriented cartoons and celebrities: images of licensed cartoon characters, e.g. Britannia Tiger; images of unlicensed cartoon characters, e.g. generic cartoons; images of sporting or entertainment celebrities.

3. Claims about health and nutrition.

Data were analysed through SPSS 17.0 and simple descriptive statistics along with chi-square were derived.

\section{DATA ANALYSIS}

The secondary data collected from the packages of food items have been analysed across Indian companies and multinationals (MNCs) that market foods in India and presented here. A description of packaged foods included in the overall sample as well as for Indian companies and MNCs is given in Table 1. 
Tab. 1 - Nature of Packaged Foods Included in the Sample. Source: author's own

\begin{tabular}{|l|c|c|c|c|c|c|}
\hline \multirow{2}{*}{ Foods } & \multicolumn{2}{|c|}{ Overall } & \multicolumn{2}{c|}{ Indian Companies } & \multicolumn{2}{c|}{ MNCs } \\
\cline { 2 - 7 } & $\mathrm{N}$ & Per cent & $\mathrm{N}$ & Per cent & $\mathrm{N}$ & Per cent \\
\hline Confectionery & 24 & 22.4 & 10 & 11.7 & 14 & 23.0 \\
\hline Baked Foods & 24 & 22.4 & 12 & 26.1 & 11 & 18.0 \\
\hline RTC Foods & 6 & 5.6 & 2 & 4.3 & 4 & 6.6 \\
\hline Snacks & 26 & 24.3 & 12 & 26.1 & 14 & 23.0 \\
\hline Beverages & 19 & 17.8 & 5 & 10.9 & 15 & 24.6 \\
\hline Ice-creams & 8 & 7.5 & 5 & 10.9 & 3 & 4.9 \\
\hline Total & 107 & 100.0 & 46 & 43.0 & 61 & 57.0 \\
\hline
\end{tabular}

The above table shows that the overall sample of 107 foods include confectionery, baked foods, RTC foods, snacks, beverages and ice-creams in the respective proportions - 22.4, 22.4, 5.6, 24.3, 17.8 and 7.5 .

The nature of marketing techniques used on food packages are shown in Table 2.

From Table 2 it is seen that most of the marketers (77.6\%) use bright pack colours to attract children. Seventy one per cent of them also use captions about flavour and one-third of them (nearly) use nutrition claims on packages to woo children. In addition to this, they also use licensed cartoon characters on packages or captions about unusual food shapes or colours as seen on twenty to twenty five per cent packages. However, the most important finding is that all marketing techniques are found on food packages. It suggests that use of promotions on packaging as a marketing tool is emerging in the Indian market.

Tab. 2 - Marketing Techniques Used to Promote Foods. Source: author's own

\begin{tabular}{|l|c|c|c|c|c|c|c|}
\hline \multirow{2}{*}{} & \multicolumn{2}{|c|}{ Overall } & \multicolumn{2}{c|}{$\begin{array}{c}\text { Indian Compa- } \\
\text { nies }\end{array}$} & \multicolumn{2}{c|}{ MNCs } & \\
\cline { 2 - 9 } & $\mathrm{N}$ & Per cent & $\mathrm{N}$ & Per cent & $\mathrm{N}$ & Per cent & P value \\
\hline Bright pack colours & 83 & 77.6 & 37 & 80.4 & 46 & 75.4 & 0.353 \\
\hline Image of child & 1 & 0.9 & 0 & 0.0 & 1 & 1.6 & --- \\
\hline $\begin{array}{l}\text { Cartoonish script or cray- } \\
\text { oned font }\end{array}$ & 37 & 34.6 & 11 & 23.9 & 26 & 42.6 & $\mathbf{0 . 0 3 4}$ \\
\hline $\begin{array}{l}\text { Caption about fun/play/ } \\
\text { crazy/educational }\end{array}$ & 12 & 11.3 & 3 & 6.5 & 9 & 14.8 & ----- \\
\hline Caption about flavour & 76 & 71.0 & 32 & 69.6 & 44 & 72.1 & 0.469 \\
\hline $\begin{array}{l}\text { Caption about unusual food } \\
\text { shape or colour }\end{array}$ & 23 & 21.5 & 9 & 19.6 & 14 & 23.0 & 0.430 \\
\hline Use of cartoon (licensed) & 27 & 25.2 & 11 & 23.9 & 16 & 26.2 & 0.483 \\
\hline Use of cartoon (unlicensed) & 7 & 6.6 & 3 & 6.5 & 4 & 6.6 & ----- \\
\hline
\end{tabular}




\begin{tabular}{|l|c|c|c|c|c|c|c|}
\hline Nutrition claims & 34 & 31.8 & 10 & 21.7 & 24 & 39.3 & $\mathbf{0 . 0 4 1}$ \\
\hline Popular characters & 10 & 9.4 & 5 & 11.4 & 5 & 8.5 & 0.434 \\
\hline Novelty packaging & 15 & 14.0 & 5 & 10.9 & 10 & 16.4 & 0.300 \\
\hline Cross promotions & 2 & 1.9 & 1 & 2.2 & 1 & 1.6 & ------ \\
\hline Premiums & 5 & 4.7 & 2 & 4.3 & 3 & 4.9 & ----- \\
\hline Price promotions & 14 & 13.2 & 7 & 15.2 & 7 & 11.5 & 0.387 \\
\hline
\end{tabular}

(Note: Percentages sum to greater than 100 due to multiple responses. For cell counts less than 5 , chi-square has not been applied)

A comparison of marketing promotions used by Indian companies versus MNCs reveals that bright pack colours are most commonly used on food packages marketed by Indian companies as well as MNCs. This is seen in 80.4 per cent and 75.4 per cent foods respectively for Indian companies and MNCs. This is followed by using captions about flavour on 69.6 per cent and 72.1 per cent food packages respectively by Indian companies and MNCs. However, MNCs use certain marketing tools more frequently as compared to Indian food marketers. These include use of cartoonish scripts/crayoned fonts (42.6\% versus $23.9 \%$ ), nutrition claims $(39.3 \%$ versus $21.7 \%$ ) novelty packaging $(16.4 \%$ versus $10.9 \%)$ and captions about fun/play/crazy/educational $(14.8 \%$ versus $6.5 \%)$. Interestingly, price promotions are used more commonly by Indian companies $(15.2 \%)$ as compared to MNCs $(11.5 \%)$.

In order to check whether statistically significant differences exist in use of marketing strategies by Indian companies and MNCs, the following null hypothesis has been tested- "There is no significant difference in use of marketing strategies by Indian companies and MNCs" using chisquare test. The p-values, as shown in the last column of the table, depict that Indian companies and MNCs differ with respect to use of 'cartoonish scripts or crayoned fonts' and 'nutritional claims' on food packages, at 5\% level of significance. However, no significant differences are observed for use of other strategies.

Tab. 3 - Use of Aggregated Marketing Techniques. Source: author’s own

\begin{tabular}{|l|c|c|c|c|c|c|c|}
\hline \multirow{2}{*}{} & \multicolumn{2}{|c|}{ Overall } & \multicolumn{2}{c|}{ Indian Companies } & \multicolumn{2}{c|}{ MNCs } & \\
\cline { 2 - 8 } & $\mathrm{N}$ & Per cent & $\mathrm{N}$ & Per cent & N & Per cent & p-value \\
\hline Semiotics & 106 & 99.1 & 45 & 42.5 & 61 & 57.5 & 0.430 \\
\hline Cross promotions & 2 & 1.9 & 1 & 2.2 & 1 & 1.6 & ----- \\
\hline Premiums & 5 & 4.7 & 2 & 4.3 & 3 & 4.9 & ----- \\
\hline Novelty Packaging & 15 & 14.0 & 5 & 10.9 & 10 & 16.4 & 0.300 \\
\hline Price promotions & 14 & 13.1 & 7 & 15.2 & 7 & 11.5 & 0.387 \\
\hline
\end{tabular}

(Note: Percentages sum to greater than 100 due to multiple responses. For cell counts less than 5, chi-square has not been applied)

Table 3 depicts that semiotics which includes use of graphics, cartoons and celebrities and claims on nutrition is the most sought after technique used by marketers as it is found on 99.1 per cent packages. This is followed by use of novelty packaging $(14.0 \%)$ or price promotions $(13.1 \%)$. 
More so, semiotics and novelty packaging are more frequently used on foods marketed by MNCs while price promotions are more frequently used by Indian food marketers. However, the two set of companies do not differ significantly with respect to use of marketing strategies on an aggregate basis.

Tab. 4 - Use of Marketing Techniques across Food Categories. Source: author's own

\begin{tabular}{|l|l|}
\hline Marketing Techniques & Between food categories \\
\hline Bright pack colours & Baked foods $(25.3 \%)$, Snacks $(22.9 \%)$ \\
\hline Cartoonish script or crayoned font & $\begin{array}{l}\text { Confectionery }(27.0 \%), \\
\text { Snacks, baked foods }(21.6 \%)\end{array}$ \\
\hline Caption about fun/play/crazy/educational & ------------------- \\
\hline Caption about flavour & $\begin{array}{l}\text { Confectionery, snacks }(25.0 \%), \\
\text { Beverages }(19.7 \%)\end{array}$ \\
\hline Caption about unusual food shape or colour & Confectionery $(30.4 \%)$, Snacks $26.1 \%)$ \\
\hline Use of cartoon (licensed) & Beverages $(29.6 \%)$, Snacks $(22.2 \%)$ \\
\hline Use of cartoon (unlicensed) & Snacks $(57.1 \%)$, Beverages $(28.6 \%)$ \\
\hline Nutrition claims & Confectionery $(26.5 \%)$, Beverages $(23.5 \%)$ \\
\hline Novelty packaging & Baked foods $(21.7 \%)$, Beverages $(20.0 \%)$ \\
\hline Price promotions & Snacks $(24.3 \%)$, Confectionery $(28.6 \%)$ \\
\hline
\end{tabular}

The above table shows that snack foods are promoted using a maximum of seven promotional elements. They include use of licensed characters (57.1\%), captions about unusual food shape or colour $(30.4 \%)$, captions about flavour $(25.0 \%)$, price promotions $(24.3 \%)$, bright pack colours $(22.9 \%)$, use of licensed cartoons $(22.2 \%)$ and cartoonish script or crayoned font $(21.6 \%)$. Confectionery is promoted using five tools whereas beverages are promoted using four tools (Table 4).

Tab. 5 - Percentage of Top Three Marketing Techniques across Food Categories. Source: author's own

\begin{tabular}{|l|c|c|c|c|c|c|c|}
\hline & $\begin{array}{c}\text { Confec- } \\
\text { tionery }\end{array}$ & Baked & RTE & Snacks & $\begin{array}{c}\text { Bever- } \\
\text { ages }\end{array}$ & $\begin{array}{c}\text { Ice- } \\
\text { creams }\end{array}$ & p-value \\
\hline Price promotions & 28.6 & 7.1 & 7.1 & 35.7 & 21.4 & 0.0 & 0.547 \\
\hline Semiotics & 21.7 & 21.7 & 5.7 & 24.5 & 18.9 & 7.5 & 0.623 \\
\hline $\begin{array}{l}\text { Novelty } \\
\text { Packaging }\end{array}$ & 13.3 & 33.3 & 0.0 & 20.0 & 26.7 & 6.7 & 0.625 \\
\hline
\end{tabular}

An analysis of marketing techniques across food categories as depicted in Table 6 brings to the fore that price promotions are most widely used for snacks (35.7\%). Similarly, semiotics is also most frequently found on snack foods as seen for 24.5 per cent foods. However, novelty packaging ideas are used for promoting baked foods $(33.3 \%)$ or beverages $(26.7 \%)$. The p values were however not significant for any of the marketing strategy. 
Tab. 6 - Number of Marketing Techniques per Product. Source: author's own

\begin{tabular}{|c|c|c|}
\hline $\begin{array}{c}\text { Number of Marketing Techniques } \\
\text { per Product }\end{array}$ & $\mathrm{N}$ & Per cent \\
\hline 0 & 1 & 0.9 \\
\hline 1 & 14 & 13.1 \\
\hline 2 & 28 & 26.2 \\
\hline 3 & 24 & 22.4 \\
\hline 4 & 15 & 14.0 \\
\hline 5 & 16 & 15.0 \\
\hline 6 & 9 & 8.4 \\
\hline
\end{tabular}

Table 6 shows that at the most six techniques have been used together to market foods. However, most of the products are marketed using two to three techniques on the package.

\section{DISCUSSION}

An analysis of marketing techniques used by companies in India demonstrates that most of the marketers use at least one promotional element on food packages to attract children. Semiotics, which includes use of graphics, cartoons and celebrities and claims on nutrition, is the most sought after technique used by marketers as it is found on almost all packages. More specifically, bright colours, captions about flavour, nutrition claims, licensed cartoon characters and captions about unusual food shapes or colours are most frequently used. However, the most important finding is that almost all marketing techniques are found on food packages to suggest that use of packaging as a marketing tool is emerging in the Indian market. More so, multiple promotions are also seen on food packages. These findings are in consonance with the findings of previous researchers (for example Chapman et al, 2006, Harris et al., 2010, Mehta et al., 2012) who have primarily carried out this research in developed countries. The nature of promotions is also closely similar. Snack foods, confectionary and beverages (which are accepted as unhealthy foods owing high fat/salt/sugar content) are heavily promoted through as array of promotional tools. MNCs use marketing tools more aggressively in order to market foods to children as compared to Indian companies. It is also noteworthy that use of some promotional tools on foods by Indian companies is also comparable with practices of MNCs. Nonetheless, the extent to which promotions are used in India is noteworthy as it is also very close to the practices followed in those countries. This reflects that Indian children are being exposed to food promotions through packaging much in the same manner as children in other developed countries of the world. The present study also empirically validates the findings of Cairns et al. (2013) that food promotions in low-middle income countries are similar to the ones used in the developed ones.

Evidence from other developed countries dictate that these activities lead to eating disorders in children and have serious negative effects on health of children (Consumers International, 2008). Use of creative marketing tactics to reach children have reached alarming levels so much so that parents and consumer groups have been forced to express the need for regulation of marketing activities of food companies (Morley et al., 2008, Miryala, 2011, Singh and Kaur, 
2012). It is found that governments in those countries have also initiated some measures to monitor and regulate promotion of foods to children (Hawkes, 2004). But, it is noteworthy that overall regulation of marketing activity has been accepted only in few countries, while a large number of countries rely on self-regulation (Caraher et al., 2005, Hawkes, 2007) whose implementation is weak (Garde, 2007, Adams et al., 2009, King et al., 2010, Hebden et al., 2011). In this situation, it is further seen that although packaging serves as an important medium to attract children to buy, yet, little or no attention is being paid towards monitoring this medium as a tool for marketing foods to children (Hawkes, 2010, Hebden, 2011). Hawkes (2010) asserts that regulation of food marketing directed at children will lose its effectiveness as packaging is not at all covered under pledges taken by companies marketing to children. Therefore, on the basis of findings of the present study, it is suggested that the government should take immediate actions to identify gaps in regulations framed for marketers. The draft regulations on labelling suggest that nutrition marketing on food packaging has not been sufficiently included. Steps should also be taken to generate public service announcements and make the consumers (children as well as their parents) more media literate. It should also monitor marketing activities directed at children through food packaging. The marketers, themselves, should also at least devise a code for using packaging as a method to promote unhealthy foods to children. This can be similar to company specific voluntary measures for food and beverage advertising to children already adopted by seven major food marketers in India (Mukherji, 2010). They should also pledge to lessen the use of packaging tactics such as use of semiotics, novelty packaging etc. towards children of very small age to act more responsibly. Packaging elements should be used as a tool to motivate children to buy healthier foods (de Droog et al., 2012) instead of low-nutritional and high-calorie foods. Therefore, marketers should rather use packaging to encourage good and healthy eating habits in children.

\section{Limitations of the study}

There are some limitations to this study. The sample size of products packages is somewhat small due to time constraint. However, the sample size does give us a general idea of how promotions are targeted at children. More so, foods have been included if they are found to be consumed by children. Any specific criteria such as use of actual promotional claim on product leading to selection of that product have not been used for the present study.

\section{Suggestions for further research}

The findings of the present study put forth that that food companies use various marketing techniques to target children. The present study has tried to identify the impact of promotions by examining what children eat firstly, and then uncover the nature of marketing strategies used on the package. Future research can identify the manner in which promoted foods are placed and made available to children in retail stores. Then selection of foods can be done to reveal the nature of foods promoted in the marketplace that try to seek a place in consumption basket of children or their parents. They can further explore the effectiveness of these strategies by analysing the impact of these promotions on acceptance of promoted foods and their subsequent purchases (by children and/or their parents) through the use of primary information. Similarly, retail store strategies can be studied to uncover the use of store design and layout elements in strengthening the impact of promotions on food packages such as stocking foods in reachable shelf locations to attract children. 


\section{References}

1. Adams, J., Hennessy-Priest, K., Ingimarsdóttir, S., Sheeshka, J., Østbye, T., \& White, M. (2009). Changes in food advertisements during 'Prime Time' television from 1991 to 2006 in the UK and Canada. British Journal of Nutrition, 102(4), 584-593. http://dx.doi.org/10.1017/ S0007114509220848

2. Atkin, C. (1978). Observation of parent-child interaction in supermarket decision-making. Journal of Marketing, 42(4), 41-45. http://dx.doi.org/10.2307/1250084

3. Berry, B., \& McMullen, T. (2008). Visual communication to children in the supermarket context: health protective or exploitive?. Agriculture and Human Values, 25(3), 333-348. http:// dx.doi.org/10.1007/s10460-007-9110-0

4. Cairns, G., Angus, K., \& Hastings, G. (2009). The extent, nature, and effects of food promotion to children: a review of the evidence to December 2008. Geneva: World Health Organization Press.

5. Cairns, G., Angus, K., Hastings, G., \& Caraher, M. (2013). Systematic reviews of the evidence on the nature, extent and effects of food marketing to children. A retrospective summary. Appetite, 62(March), 209-215. http://dx.doi.org/10.1016/j.appet.2012.04.017

6. Caraher, M, Landon, J., \& Dalmeny, K. (2006). Television advertising and children: lessons from policy development. Public Health Nutrition, 9(5), 596-605. http://dx.doi.org/10.1079/ PHN2005879

7. Carruth, B. R., Skinner, J. D., Moran, J. D., \& Coletta, F. (2000). Preschoolers' food product choices at a simulated point of purchase and mothers' consumer practices. Journal of Nutrition Education, 32(3), 146-151. http://dx.doi.org/10.1016/S0022-3182(00)70542-5

8. Chadha R., Bhatiani, R., \& Dutta, S.M. (2010). Opportunities in the packaged food market in India. Technopak Perspective, 3, 83-89.

9. Chan, K., \& McNeal, J.U. (2003). Parent-child communication about consumption and advertising in China. Journal of Consumer Marketing, 20(4), 317-334. http://dx.doi.org/10.1108 /07363760310483685

10. Chapman, K., Nicholas, P., Banovic, D., \& Supramaniam, R. (2006). The extent and nature of food promotion directed to children in Australian supermarkets. Health Promotion International, 21(4), 331-333. http://dx.doi.org/10.1093/heapro/dal028

11. Chareonsakdi, T. (2009). Package design for children: do practitioners get it right?. Master Thesis. Auckland University of Technology. Retrieved from: http://aut.researchgateway.ac.nz/ handle/10292/892

12. Consumers International (2008). The Junk. Food Trap, marketing unbealtby food to children in Asia Pacific. Retrieved from: www.consumersinternational.org

13. de Droog, S. M., Buijzen, M., \& Valkenburg, P. M. (2012). Use a rabbit or a rhino to sell a carrot? The effect of character-product congruence on children's liking of healthy foods. Journal of Health Communication: International Perspectives, 17(9), 1068-1080. http://dx.doi. org $/ 10.1080 / 10810730.2011 .650833$

14. Elliot, C. (2008). Assessing 'fun foods': Nutritional content and analysis of supermarket foods targeted at children. Obesity Reviews, 9(4), 368-377. http://dx.doi.org/10.1111/j.1467789X.2007.00418.x 
15. Garde, A. (2008). Food advertising and obesity prevention: what role for the European Union?. Journal of Consumer Policy, 31(1), 25-44. http://dx.doi.org/10.1007/s10603-007-9061-2

16. Gelperowic, R., \& Beharrell, B. (1994). Healthy food products for children: packaging and mothers purchase decisions. British Food Journal, 96(11), 4-8. http://dx.doi.org/10.1108/0007 0709410074623

17. Harris, J. L, Schwartz, M. B., \& Brownell, K. D. (2010). Marketing foods to children and adolescents: licensed characters and other promotions on packaged foods in the supermarket. Public Health Nutrition, 13(3), 409-417. http://dx.doi.org/10.1017/ S1368980009991339

18. Hawkes, C. (2004). Marketing food to children: the global regulatory environment. Geneva: World Health Organization Press. Retrieved from: http://whqlibdoc.who.int/publications/2004/ 9241591579.pdf

19. Hawkes, C. (2007). Regulating and litigating in the public interest. American Journal of Public Health, 97(11), 1962-1973. http://dx.doi.org/10.2105/AJPH.2006.101162

20. Hawkes, C. (2010). Food packaging: the medium is the message. Public Health Nutrition, 13(2), 297-299. http://dx.doi.org/10.1017/S1368980009993168

21. Hebden, L, King, L., Kelly, B. Chapman, K., \& Innes-Hughes, C. (2011). A menagerie of promotional characters: promoting food to children through food packaging. Journal of Nutrition Education and Behaviour, 43(5), 349-355. http://dx.doi.org/10.1016/j.jneb.2010.11.006

22. Kaiser Family Foundation. (2007). Television food advertising to children in the United States. Food for thought. Menlo Park, CA: The Henry J. Kaiser Family Foundation. Retrieved from: http://www.kff.org/entmedia/7618.cfm

23. Kaur, P., \& Singh, N. (2010). Children's purchase influence and parental responses. A Project Report submitted to Department of Commerce and Business Management, Guru Nanak Dev University, Amritsar.

24. King, L., Hebden, L., Grunseit, A., Kelly, B., Chapman, K., \& Venugopal, K., (2010). Industry self-regulation of television food advertising: responsible or responsive?. International Journal of Pediatric Obesity, 6(2-2), 390-398. http://dx.doi.org/10.3109/17477166.2010.517313

25. Macklin, M.C. (1996). Preschoolers' learning of brand names from visual cues. Journal of Consumer Research, 23(3), 251-261. http://dx.doi.org/10.1086/209481

26. Maher, J.K., Lord, J.B., Hughner, R.S., \& Childs, N.M. (2006). Food advertising on children's television. Young Consumers: Insight and Ideas for Responsible Marketers, 7(4), 41 - 52. http://dx.doi.org/10.1108/17473610610717964

27. Mehta, K., Philips, C., Banytis, F., Ward, P., Coveney, J., \& Handsley, E. (2010). Report on marketing food and beverages to children via product pack aging in supermarkets. Children and Food Marketing Project Report to SA Health. Flinders University. Retrieved from: http://foodlabellingreview.gov.au/internet/foodlabelling/submissions.nsf/ lookupSubmissionAttachments/1ATAN-85Z5UE20100601131549FJVA/\$FILE/683.pdf

28. Mehta, K., Phillips, C., Ward, P., Coveney, J., Handsley, E., \& Carter, P. (2012). Marketing foods to children through product packaging: prolific, unhealthy and misleading. Public Health Nutrition, 15(9), 1763-1770. http://dx.doi.org/10.1017/S1368980012001231 
29. Meyers, H. M., \& Lubliner, M. J. (1998). The Marketer's Guide to Successful Package Design. Chicago: Lincolnwood.

30. Miryala, R.K. (2011). Advertisements' effect on food habits of children-an empirical study. Indian Journal of Commerce \& Management Studies, 2(4), 38-49.

31. Morley, B., Chapman, K., Mehta, K., King, L., Swinburn, B., \& Wakefield, M. (2008). Parental awareness and attitudes about food advertising to children on Australian television. Australian and New Zealand Journal of Public Health, 32(4), 341-347. http://dx.doi. org/10.1111/j.1753-6405.2008.00252.x

32. Mukherji, J. (2005). Maternal communication patterns, advertising attitudes and mediation behaviours in urban India. Journal of Marketing Communications, 11(4), 247-262. http://dx.doi. org/10.1080/13527260500167223

33. Mukherji, S. (2010). 7 Majors Pledge Responsible Advertising. The Tribune, July 19, 2010. Retrieved July 20, 2010, from: www.tribuneindia.com

34. National Institute of Nutrition (2010). Dietary guidelines for Indians. A Manual published by National Institute of Nutrition, Hyderabad.

35. Neeley, S., \& Schumann, D. (2004). Using animated spokes-characters in advertising to children. Journal of Advertising, 33(3), 7-23. http://dx.doi.org/10.1080/00913367.2004.10639 166

36. Ogba, I. E., \& Johnson, R. (2010). How packaging affects the product preferences of children and the buyer behaviour of their parents in the food industry. Young Consumers: Insight and Ideas for Responsible Marketers, 11(1), 77-89. http://dx.doi.org/10.1108/17473611011 026037

37. Page, R.M., \& Brewster, A. (2007). Frequency of Promotional Strategies and Attention Elements in Children's Food Commercials during Children's Programming Blocks on US Broadcast Networks. Young Consumers. Insight and Ideas for Responsible Marketers, 8(3), 184196. http://dx.doi.org/10.1108/17473610710780936

38. Page, R., Montgomery, K., Ponder, A., \& Richard, A. (2008). Targeting children in the cereal aisle: Promotional techniques and content features on ready-to-eat cereal product packaging. American Journal of Health Education, 39(5), 272-282. http://dx.doi.org/10.1080/19 325037.2008.10599050

39. Roberts, M. (2005). Parenting in an obesogenic environment. Journal of Research for Consumers, 2005(9), 1-11.

40. Singh, R., \& Kaur, P. (2012). Ethics in food advertising to children: parental concerns and mediation. A Project Report submitted to All India Council of Technical Education, New Delhi.

41. Ulger, B. (2009). Packages with cartoon trade characters versus advertising: an empirical examination of preschoolers' food preferences. Journal of Food Products Marketing, 15(1), 104117. http://dx.doi.org/10.1080/10454440802470649

42. Ulger, G., \& Ulger, B. (2012). Children in family purchase decision-making: children's role in food product purchases from mothers' point of view. Journal of Marketing Communications, 18(4), 297-320. http://dx.doi.org/10.1080/13527266.2010.528994 
43. Wilson, G., \& Wood, K. (2004). The influence of children on parental purchases during supermarket shopping. International Journal of Consumer Studies, 28(4), 329-336. http://dx.doi. $\operatorname{org} / 10.1111 / \mathrm{j} .1470-6431.2004 .00393 . x$

44. Witkowski, T. H. (2007). Food marketing and obesity in developing countries: analysis, ethics and public policy. Journal of Macromarketing, 27(2), 126-137. http://dx.doi.org/10.1177/ 0276146707300076

45. Young, S. (2003). Winning at retail: research insights to improve the packaging of children's products. Young Consumers. Insight and Ideas for Responsible Marketers, 5(1), 17-22. http://dx.doi.org/10.1108/17473610410814012

\section{Contact Information}

Dr. Pavleen Soni, MBA, PHD

Department of Commerce and Business Management

Guru Nanak Dev University

Amritsar-143005, India

Email:topavleen@yahoo.co.in 